\title{
Activity and expression of polygalacturonase vary at different fruit ripening stages of sweet pepper cultivars
}

\author{
S.S. Ahmed ${ }^{1}$, Z.-H. Gong ${ }^{1}$, M.A. Khan ${ }^{1,2}$, Y.-X. Yin ${ }^{1}$, W.-L. Guo ${ }^{1}$ and \\ J. Imran ${ }^{1}$ \\ ${ }^{1}$ College of Horticulture, Northwest A \& F University, Yangling, \\ Shaanxi, P.R. China \\ ${ }^{2}$ PMAS-Arid Agriculture University, Rawalpindi, Pakistan \\ Corresponding author: Z.-H. Gong \\ E-mail: gzhh168@yahoo.com.cn
}

Genet. Mol. Res. 10 (4): 3275-3290 (2011)

Received July 7, 2011

Accepted November 16, 2011

Published November 22, 2011

DOI http://dx.doi.org/10.4238/2011.November.22.10

\begin{abstract}
Activity and expression of polygalacturonase (PG), a hydrolytic enzyme involved in ultrastructural changes in the pericarp of sweet pepper (Capsicum annaum), were investigated at different ripening stages of the pepper cultivars Mandi and Talanduo. Molecular cloning of $\mathrm{CaPG}$ was carried out by constructing a cDNA library from three stages of fruit ripening. Morphological determination, PG assay, RT-PCR, and ultrastructural studies were used to quantify changes in $C a P G$ gene expression in the pericarp from green, color change and fully ripened stages. We found that CaPG gene expression, $\mathrm{PG}$ activity and striking changes in the structure of the cell wall occurred with the transition of ripening stages. CaPG gene expression was high (obvious PCR products) in mature and ripened stages of both cultivars; however, the $C a P G$ gene was not expressed in preclimacteric fruits or vegetative tissues. We conclude that developmental regulation of $\mathrm{CaPG}$ gene expression is instrumental for sweet pepper fruit ripening; its expression during
\end{abstract}


development leads to dissolution of middle lamella and eventually disruption of the fully ripened cell wall.

Key words: Sweet pepper; Polygalacturonase; RT-PCR; Ultrastructure; Cell wall; Transmission electron microscopy

\section{INTRODUCTION}

Fruit maturity of horticultural commodities is a complex and sometimes erratic phenomenon. It is believed that transition of fruit ripening is the result of a complex developmental program influencing metabolic processes in each compartment of the cell. Primarily, this developmental program occurs due to the degradation of pectic polymers in the cell wall, which is brought about by the action of ripening-induced enzymes, such as polygalacturonase (PG) (Themmen et al., 1982; Crookes and Grierson, 1983; Huber, 1983; Giovannoni et al., 1989; Osteryoung et al., 1990). Although the ripening mechanism has been widely studied and reviewed, it is still far from being clearly understood (Brady, 1987). Some authors have reported that the fruit softening is largely associated with breakdown of the fruit cell wall (Crookes and Grierson, 1983; Osteryoung et al., 1990; Rao and Paran, 2003). The primary cell wall is composed of several polymers, including cellulose, glycans and pectins that are modified during fruit ripening (Brummell and Harpster, 2001; Giovannoni, 2001). The ripening of fruit is characterized by a series of coordinated biochemical and physiological changes, which collectively leads into the final texture, color and taste of the mature fruit (DellaPenna et al., 1987).

The effect of several cell wall-modifying enzymes on fruit ripening and softening has been studied in many plant species, the most intensively studied of these enzymes being PG. PG is one of the most active and paramount agents of fruit aging and cell wall softening. The normal role of PG is to hydrolyze pectins during fruit ripening, which leads to softening of the fruit (Fenwick et al., 1996; Errington et al., 1997; Rao and Paran, 2003). In tomatoes, the high level of endo-PG activity detected in ripe fruits has led to the hypothesis that PG plays an important role in fruit softening (Giovannoni et al., 1991).

Softening of the tomato fruit during ripening has been studied extensively over the last 20 years, and a large body of evidence has accumulated, suggesting that the cell wall enzyme PG plays an inevitable role in this process (DellaPenna et al., 1987). The softening phenomenon influenced by PG in fruits like apples, cherries, dates, durians, grapes, kiwis, melons, peaches, pears, pineapples, tobacco, and tomatoes during ripening has been studied during the past two decades and substantial evidence has been collected, suggesting that the cell wall enzyme PG plays a major role in the entire ripening process (Hobson, 1965; Hasegawa et al., 1969; Ahmed and Labavitch, 1980; Paull and Chen, 1983; Osteryoung et al., 1990; Barrett and Gonzalez, 1994; Ketsa et al., 1998; Ketsa and Daengkanit, 1999).

In recent years, interest on demand for peppers has increased dramatically worldwide and peppers have achieved major economic significance in the global markets (Georgia et al., 2010). The fruit tissue disintegration and the deciduous fruit trait in tabasco pepper are the result of loss of cell-to-cell adhesion as a consequence of pectin ultradegradation and cell wall dissolution (Arancibia and Motsenbocker, 2006).

However, very little information is available regarding solubilization of the cell wall 
due to the action of cell wall hydrolytic enzymes like PG in the pepper crop at molecular and ultrastructural levels. Previously the loss of cohesion in the cell wall and middle lamella has been observed by electron microscopy in a number of species, but this still remains unexplained in molecular terms (Crookes and Grierson, 1983; Seymour and Gross, 1996).

We used RT-PCR coupled with electron microscopy to evaluate the influence of the cell wall-degrading enzyme PG on fruit ripening of sweet pepper cultivars at three different stages.

\section{MATERIAL AND METHODS}

\section{Plant material}

Sweet pepper cv. Mandi (MD) (turns red at fruit ripening) and cv. Talanduo (TLD) (turns yellow at fruit ripening) were obtained from the Northwest A \& F University, College of Horticulture, People's Republic of China. Fruits that were approximately uniform in size, color and that were free from foreign contamination were selected from both cultivars for the experiment.

\section{Morphological aspects}

All the fruits were measured for their fresh fruit weight, fruit length, fruit width, and pericarp width at three different fruit ripening stages, characterized as green, breaker and fully ripened. Observations were made regarding changes that occurred exclusively in those parts of the fruits that are considered to be affected largely by PG during different ripening stages (Geleta et al., 2005; Del et al., 2007); these were correlated with the production of PG. Ten fruits were selected from each cultivar, replicated five times for each parameter. Data were obtained after an interval of 10 days from the transition to each fruit ripening stage.

\section{Polygalacturonase assay}

PG activity can be assayed by both reductometric and viscometric methods. Since the viscometric method is not specific for PG and certain other enzymes may also contribute to viscosity reduction (Yoshida and Komae, 2006), the reductometric method was used.

\section{Collection of crude enzyme}

Fruit pericarps $5 \mathrm{~g}$ in weight at the particular reproductive stage were excised with a sharp knife and were thoroughly ground in liquid nitrogen, followed by incorporation of $20 \mathrm{~mL}$ extraction buffer. All the samples were subjected to vigorous shaking with the $\mathrm{pH}$ previously adjusted at 6.0. Samples were centrifuged at $5000 \mathrm{~g}$ for $10 \mathrm{~min}$. Subsequently, the supernatant was collected and then $75 \%\left(\mathrm{NH}_{4}\right)_{2} \mathrm{SO}_{4}$ was added to precipitate the protein. All the samples were kept on ice for $1 \mathrm{~h} ; 5-8 \mathrm{~mL}$ supernatant was poured into polythene tubes and carefully sealed with clips, then immersed in $1 \mathrm{~L} 75 \%\left(\mathrm{NH}_{4}\right)_{2} \mathrm{SO}_{4}$ for shaking over night. The procedure followed was according to Peigen et al. (1991). 


\section{Determination of enzyme activity}

PG activity was assayed according to the method described by Peigen et al. (1991). The reaction mixture was $10 \mathrm{~mL}$ 1\% (w/v) $\alpha$-D-polygalacturonic acid (D-PG; Sigma) in 0.2 $\mathrm{M}$ sodium acetate buffer, $\mathrm{pH} 4.5$, and $10 \mathrm{~mL}$ crude enzyme. Each control tube contained $10 \mathrm{~mL}$ substrate. The blank control was developed by boiling $10 \mathrm{~mL} \mathrm{1 \%} \mathrm{D-PG} \mathrm{and} 10 \mathrm{~mL}$ of the crude enzyme for $5 \mathrm{~min}$. Simultaneously, $10 \mathrm{~mL} \mathrm{1 \%} \mathrm{D-PG} \mathrm{and} 10 \mathrm{~mL}$ of the crude enzyme were also obtained for monitoring the enzyme activity at the particular stage of pepper development. The experimental and control tubes were incubated in a water bath at $50^{\circ} \mathrm{C}$ for $2 \mathrm{~h}$ to provide ample time for the reaction to take place, followed by $5 \mathrm{~min}$ of boiling to terminate the reaction. All the samples were treated with $5 \mathrm{~mL} 1 \mathrm{M} \mathrm{Na}_{2} \mathrm{CO}_{3}$ and $20 \mathrm{~mL} 0.1 \mathrm{M} \mathrm{I}_{2}-\mathrm{KI}$ and were kept in the dark for $20 \mathrm{~min}$ to promote the chemical reaction. After completion of the reaction, $10 \mathrm{~mL} 1 \mathrm{M} \mathrm{H}_{2} \mathrm{SO}_{4}$ was added, followed by dripping of $0.05 \mathrm{M} \mathrm{NaS}_{2} \mathrm{O}_{3}$ until the color turned yellow. The total reducing sugar was quantified by the dinitrosalicylic method (Arancibia and Motsenbocker, 2006). Readings of enzyme activity were calculated by the use of the following formula according to Peigen et al. (1991). The unit of PG activity can be described as the amount of enzyme that catalyzes the formation of $1 \mu \mathrm{mol}$ of reducing group per hour. PG is capable of releasing reducing groups from the substrate PG acid or pectic acid. The quantity of reducing groups released is the measure of the enzyme activity.

$$
\mathrm{PG}=[(\mathrm{B}-\mathrm{A}) \times \mathrm{M} \times 0.51] /(\mathrm{E} \times \mathrm{T})
$$

where $\mathrm{A}=$ volume of $\mathrm{NaS}_{2} \mathrm{O}_{3}$ added in the sample; $\mathrm{B}=$ volume of $\mathrm{NaS}_{2} \mathrm{O}_{3}$ added in the blank control; $\mathrm{M}=$ molar concentration of $\mathrm{NaS}_{2} \mathrm{O}_{3}$, i.e., $0.05 \mathrm{~mol} ; \mathrm{E}=$ volume of crude enzyme used in the reaction, and $\mathrm{T}=$ time for the completion of chemical reaction, i.e., $2 \mathrm{~h}$.

\section{RT-PCR}

\section{cDNA library}

Fruit pericarp of the corresponding reproductive stage was thoroughly ground in liquid nitrogen and RNA was extracted. Total RNA was extracted with an Invisorb-Spin PlantRNA Mini Kit (Invitek, Berlin, Germany). This was then treated with RNase-free DNase-I (Xue and Loveridge, 2004) to remove possible contaminating DNA. The remaining RNA was reverse-transcribed using oligo(dT) 18 primers and a RevertAid ${ }^{\mathrm{TM}}$ First-Strand cDNA Synthesis Kit. The cDNA was obtained using the M-MLV reverse transcriptase kit (Promega, Madison, WI, USA). Samples were reverse-transcribed in situ by adding an RT mix to make up a total volume of $20 \mu \mathrm{L}$. Each tube contained $4.5 \mu \mathrm{L}(1 \mu \mathrm{g}) \mathrm{RNA}$ and $0.5 \mu \mathrm{g} / \mu \mathrm{L}$ oligo(dT) 18 primer. Reverse-transcription proceeded for $60 \mathrm{~min}$ at $42^{\circ} \mathrm{C}$ before the reaction was terminated by heating to $72^{\circ} \mathrm{C}$ for $10 \mathrm{~min}$.

\section{RT-PCR operation}

Semi-quantitative RT-PCR was used to determine the strength of gene expression 
(Wang et al., 2000; Li et al., 2010; Zhu et al., 2011). The success of reverse-transcription was validated by conducting PCR with $1 \mu \mathrm{L}$ cDNA and reference gene primers. Concentrations of cDNA were measured photometrically. The cDNA was then diluted to 10 $\mathrm{ng} / \mu \mathrm{L}$. The reaction mixture of approximately $25 \mu \mathrm{L}(1 \mu \mathrm{L}$ cDNA template; $2.5 \mu \mathrm{L} 10 \mathrm{X}$ PCR buffer, $0.2 \mu \mathrm{L} 5 \mathrm{U} / \mu \mathrm{L}$ Taq DNA polymerase; $0.5 \mu \mathrm{L} 10 \mathrm{mM}$ dNTP mixture; $16.8 \mu \mathrm{L}$ $\mathrm{ddH}_{2} \mathrm{O}$, and $1 \mu \mathrm{L}$ each of PG-F, PG-R, EFI- $\alpha-\mathrm{F}$, and EFI- $\left.\alpha-\mathrm{R}\right)$ was used for conducting $\mathrm{PCR}$. Amplification consisted of 30 cycles of $45 \mathrm{~s}$ at $94^{\circ} \mathrm{C}$ (denaturation), $60 \mathrm{~s}$ at $51^{\circ} \mathrm{C}$ (primer annealing) and $120 \mathrm{~s}$ at $72^{\circ} \mathrm{C}$ (extension) (Giorno et al., 2010). The optical density of the electrophoresis bands of $C a P G$ and $E F I-\alpha$ was detected by the gel-imaging analysis system (Syngene, Cambridge, UK). The relative expression level of $C a P G$ was represented as the ratio of the optical density of $C a P G$ to that of EFI- $\alpha$. Each treatment was performed three times. Primer sequences of the genes and their expected amplified product size are given in Table 1.

\begin{tabular}{lllc}
\multicolumn{4}{l}{ Table 1. Primer sequences of the genes used for RT-PCR along with expected amplified bands. } \\
\hline Gene name & Primer name & Primer sequence & Amplified size \\
\hline CaPG & CaPG-F & 5'-ATATTTTCCATACTTTCCTCCAT-3' & $1200 \mathrm{bp}$ \\
& CaPG-R & 5'-CTGTTGCACTTGTGCCTTT-3' & \\
& EFI- $\alpha-\mathrm{F}$ & 5'-CCACCAATCTTGTAACATCC-3' & $455 \mathrm{bp}$ \\
& EFI- $\alpha-\mathrm{R}$ & 5'-AGACCACTAAGTACTACTGCAC-3' & \\
\hline
\end{tabular}

\section{Ultrastructure studies}

Small pieces (approximately $<1 \mathrm{~mm}^{2}$ ) of fruit pericarp at the particular growth stage were excised and fixed in $4 \%(\mathrm{v} / \mathrm{v})$ glutaraldehyde in $20 \mathrm{mM}$ phosphate buffer, $\mathrm{pH} 7.0$, for $6 \mathrm{~h}$ at $4^{\circ} \mathrm{C}$, with the samples rinsed approximately 4-5 times in PBS buffer at intervals of 5, 10,15 , and $20 \mathrm{~min}$, following the procedure described by Khan et al. (2011), followed by post-fixation in $1 \%(\mathrm{w} / \mathrm{v})$ aqueous osmium tetroxide for $2 \mathrm{~h}$ at room temperature. All the fixed samples were washed again with PBS 4-5 times at intervals of 5, 10, 15, and 20 min. Fixed tissues were dehydrated through a graded alcohol series including $1 \%(\mathrm{w} / \mathrm{v})$ phosphotungstic acid in the first absolute alcohol stage, ethanol and acetone. Initially, we used ethanol with low concentrations of 30,50 and $70 \%$, at an interval of 10-15 min. Then, the dehydration was performed with increasing concentrations of 80 and $90 \%$ ethanol, at an interval of 15-20 min. Later, $100 \%$ ethanol was used twice, at an interval of $30 \mathrm{~min}$. Finally, $100 \%$ acetone was used at an interval of $30 \mathrm{~min}$. Subsequently, samples were embedded in acrylic resin (London Resin Co. Ltd.; Basingstoke, England). Sections were cut by using a Leica Ultracut UC7 device contrasted with Reynolds lead citrate and observed in a JEOL model JEM-1230 electron microscope (Tokyo, Japan).

\section{Statistical analysis}

The experiment was run in a two-factor completely randomized design with five replications. Data were analyzed through comparions of variance and means by the Duncan multiple range test at $\alpha=0.05$. Statistical analysis was performed with the M-Stats software. 


\section{RESULTS}

\section{Polygalacturonase assay}

PG activity was evaluated during the ripening stages of sweet pepper cv. MD and cv. TLD to determine its association with the extent of cell wall degradation. Rises in the PG activity were concomitant with transition of ripening stages. An increasing trend of PG activity was documented, and it was observed that PG activity increased dramatically with the transition of fruit ripening stages (Figure 1). Cultivar MD at the green stage showed limited PG activity of approximately $0.55 \mu \mathrm{mol} \mathrm{D-PG} \cdot \mathrm{h}^{-1} \cdot \mathrm{g}^{-1}$, but at the ripe stage a maximum PG activity of approximately $5.48 \mu \mathrm{mol} \mathrm{D}-\mathrm{PG} \cdot \mathrm{h}^{-1} \cdot \mathrm{g}^{-1}$ was recorded. In contrast, $\mathrm{cv}$. TLD showed limited PG activity at the green stage of approximately $1.86 \mu \mathrm{mol} \mathrm{D}-\mathrm{PG} \cdot \mathrm{h}^{-1} \cdot \mathrm{g}^{-1}$, and maximum PG activity at the ripe stage of approximately $5.10 \mu \mathrm{mol} D-\mathrm{PG} \cdot \mathrm{h}^{-1} \cdot \mathrm{g}^{-1}$. There were significant differences between different stages of the ripening but no significant difference was observed between the cultivars in terms of PG activity (Table 2).

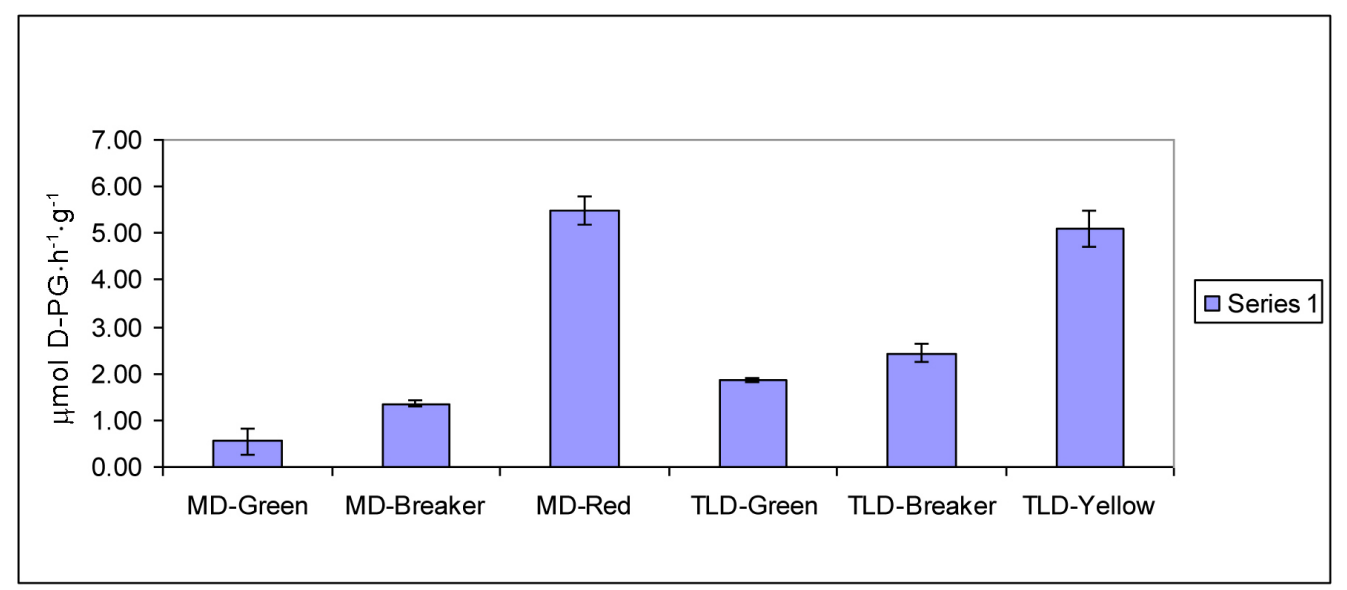

Figure 1. Different levels of PG activity exhibited in cultivars MD and TLD at their fruit ripening stages. For abbreviations, see legend to Table 2 .

\begin{tabular}{|c|c|c|c|c|c|c|}
\hline Cultivars & Ripening stages & Fruit weight (g) & Fruit length $(\mathrm{mm})$ & Fruit width $(\mathrm{mm})$ & Pericarp width (mm) & PG activity $\left(\mu \mathrm{mol}\right.$ D-PG $\left.\cdot \mathrm{h}^{-1} \cdot \mathrm{g}^{-1}\right)$ \\
\hline \multirow[t]{3}{*}{ MD } & Green & $145.54^{\text {bcd }}$ & $79.54^{\mathrm{c}}$ & $68.23^{c}$ & $6.54^{\mathrm{ab}}$ & $0.54^{\mathrm{f}}$ \\
\hline & Breaker & $164.84^{\mathrm{cd}}$ & $89.94^{\mathrm{d}}$ & $83.73^{\text {cd }}$ & $5.80^{\mathrm{b}}$ & $1.35^{\mathrm{e}}$ \\
\hline & Red & $142.34^{\mathrm{d}}$ & $76.74^{\mathrm{d}}$ & $67.44^{\mathrm{d}}$ & $5.688^{\mathrm{b}}$ & $5.48^{\mathrm{a}}$ \\
\hline \multirow[t]{3}{*}{ TLD } & Green & $157.80^{\mathrm{a}}$ & $85.67^{\mathrm{a}}$ & $82.91^{\mathrm{a}}$ & $6.96^{\mathrm{a}}$ & $1.86^{\mathrm{d}}$ \\
\hline & Breaker & $137.72^{\mathrm{ab}}$ & $75.34^{\mathrm{b}}$ & $67.05^{\mathrm{ab}}$ & $6.61^{\mathrm{ab}}$ & $2.44^{\mathrm{c}}$ \\
\hline & Yellow & $152.04^{\mathrm{bc}}$ & $84.48^{\mathrm{b}}$ & $82.22^{\mathrm{b}}$ & $6.71^{\mathrm{ab}}$ & $5.10^{\mathrm{b}}$ \\
\hline
\end{tabular}

$\mathrm{MD}=$ sweet pepper cv. Mandi; TLD = sweet pepper cv. Talanduo; D-PG $=\alpha$-D-polygalacturonic acid. Numbers followed by different superscript letters indicate significant differences at $\mathrm{P}=0.05$ (Duncan multiple range at test). 


\section{RT-PCR}

\section{The expression of the CaPG gene at different fruit ripening stages}

The results of semi-quantitative RT-PCR depicted that $C a P G$ (Chen et al., 2010) (GeneBank ${ }^{\circledR}$ accession No. FJ596175) was expressed at different fruit ripening stages of cv. $\mathrm{MD}$ and cv. TLD, and in general the expression of $C a P G$ in TLD was higher than in MD (Figure 2). Also there were some weak bands detected for $\mathrm{CaPG}$ expressed during the breaker stage of fruit ripening in both cultivars (Figure 3). However, gene expression showed increasing trend with the transition of ripening stages. In addition, $C a P G$ was strongly expressed at mature stages of both cultivars, whereas $C a P G$ was not expressed at the green stage in both cultivars (Figure 3). On the whole, the expression level of CaPG in TLD was significantly higher than in MD at the different fruit ripening stages (Figure 2).

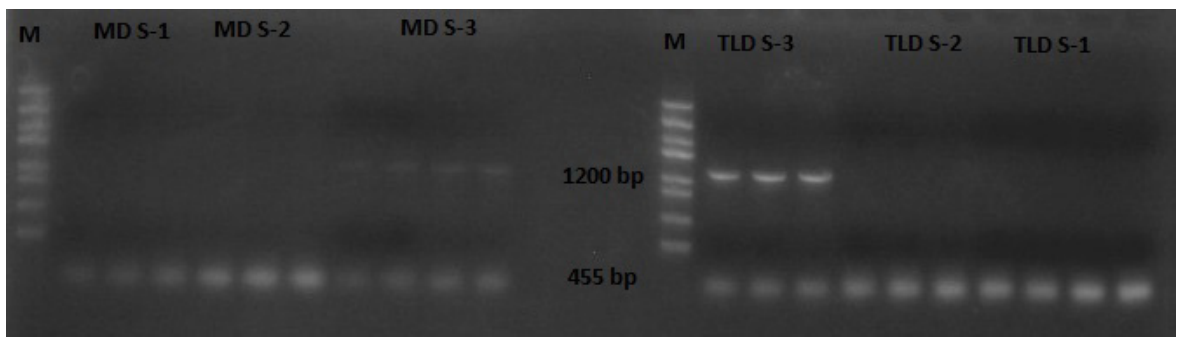

Figure 2. RT-PCR of MD and TLD cultivars exhibiting different levels of $C a P G$ gene expression including the reference gene. Lane $M=$ molecular marker. For abbreviations, see legend to Table 2 .

A.

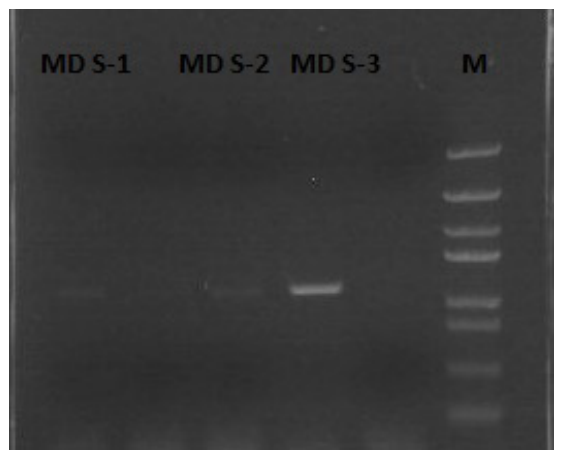

B.

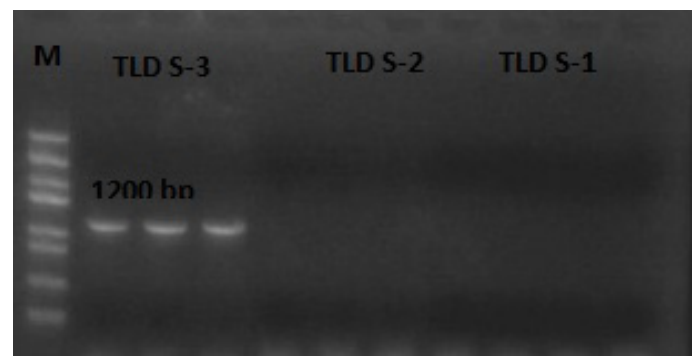

Figure 3. RT-PCR of cultivars MD (A) and TLD (B) showing diverse levels of $C a P G$ gene expression at three different fruit ripening stages. Lane $M=$ molecular marker. For abbreviations, see legend to Table 2. 


\section{Ultrastructure studies during ripening}

\section{Microscopy at the green stage}

The pericarp of mature green pepper cv. MD and cv. TLD was found to be composed of large isodiametric parenchymous cells of approximately $280 \mu \mathrm{m}$ in diameter. Observations were made using transmission electron microscopy (TEM); the cytoplasm of both cultivars was confined to a narrow layer approximately $15 \mu \mathrm{m}$ thick adjacent to the cell wall. The cytoplasm was vacuolated and included a number of common organelles, including chloroplasts containing numerous grana and plastoglobuli (Figure 4, PIC $=1$; Figure 6, PIC =8, 9 and 10), chromoplast (Figure 4, PIC $=3$; Figure 6, PIC $=8$ and 9) and mitochondria (Figure 4, PIC $=$ 1 ; Figure 6 , PIC $=9$ ). The cell wall appeared to be composed of densely packed fibrils in an electron-translucent matrix (Figure 4). The middle lamella was quite visible as a more electron-dense region between the walls of adjacent cells (Figure 4, PIC =1). It was observed that the cell wall, middle lamella and other cellular organelles of the fruits were not disintegrated and crumbled at the very beginning of fruit ripening.

\section{Microscopy at the breaker stage}

From 10-15 days after the onset of PG production in both cultivars MD and TLD from stage-I to stage-II, no undistinguishable changes were found in the cell wall and the cytoplasm of the ripening fruit cells. Fewer and smaller starch grains were observed in the chloroplasts, and crystalloid microbodies were present (Figure 4, PIC $=2,3$ and 4; Figure 6, PIC $=11$ ).

\section{Microscopy at the fully ripe stage}

After a lapse of 15-20 days and after the onset of PG production in cultivars MD and TLD, a change in the appearance of the cell wall was noted along the middle lamella (Figure 5 , $\mathrm{PIC}=6$; Figure 7, PIC = 13). Chloroplasts and mitochondria were present in cultivar MD (Figure 5; PIC = 5), but fewer in number, and immature chromoplasts appeared (Figure 5, PIC $=7$ ). On the other hand, in cv. TLD a distinguishable change was observed in interfibrillar spaces of the cell wall that clearly provided evidence of cell wall dissolution along the middle lamella. Cellular organelles like chromoplast, crystalloid microbodies and mitochondria had initiated crumbling (Figure 7, PIC $=13$ and 14). Plastid structure was altered, with angular lycopene crystalloid remnants being replaced by an intraplastid membrane system (Figure 7, PIC = 14). After 20-24 days and following the onset of PG production, cell wall disruption was much more enhanced in cv. TLD, in particular, and in cv. MD, in general (Figure 5, PIC $=7$; Figure 7, PIC $=15$ ).

\section{Morphological aspects}

Data of fruit weight, fruit length, fruit width, and pericarp width at different ripening stages showed significant differences in fruit weight and fruit length that resulted due to the increasing activity of PG, whereas no significant differences were found in fruit width and pericarp width (Table 2). Cultivars MD and TLD at the green stage gained fruit weight up to 
145.54 and $157.80 \mathrm{~g}$, followed by an erratic trend of fruit mass deposition at breaker (164.84 and 137.72) and mature stages (142.34 and $152.04 \mathrm{~g}$ ), respectively. Fruit length of cv. MD at the green stage was approximately $79.5 \mathrm{~mm}$, at the breaker stage, it was approximately 89.9 $\mathrm{mm}$, followed by a reduced fruit length of approximately $76.7 \mathrm{~mm}$ at the red mature stage. On the other hand, cv. TLD attained fruit length at the green stage of approximately $85.7 \mathrm{~mm}$; at the breaker stage it attained $75.3 \mathrm{~mm}$, and at the yellow matured stage the weight was reduced (Table 2).
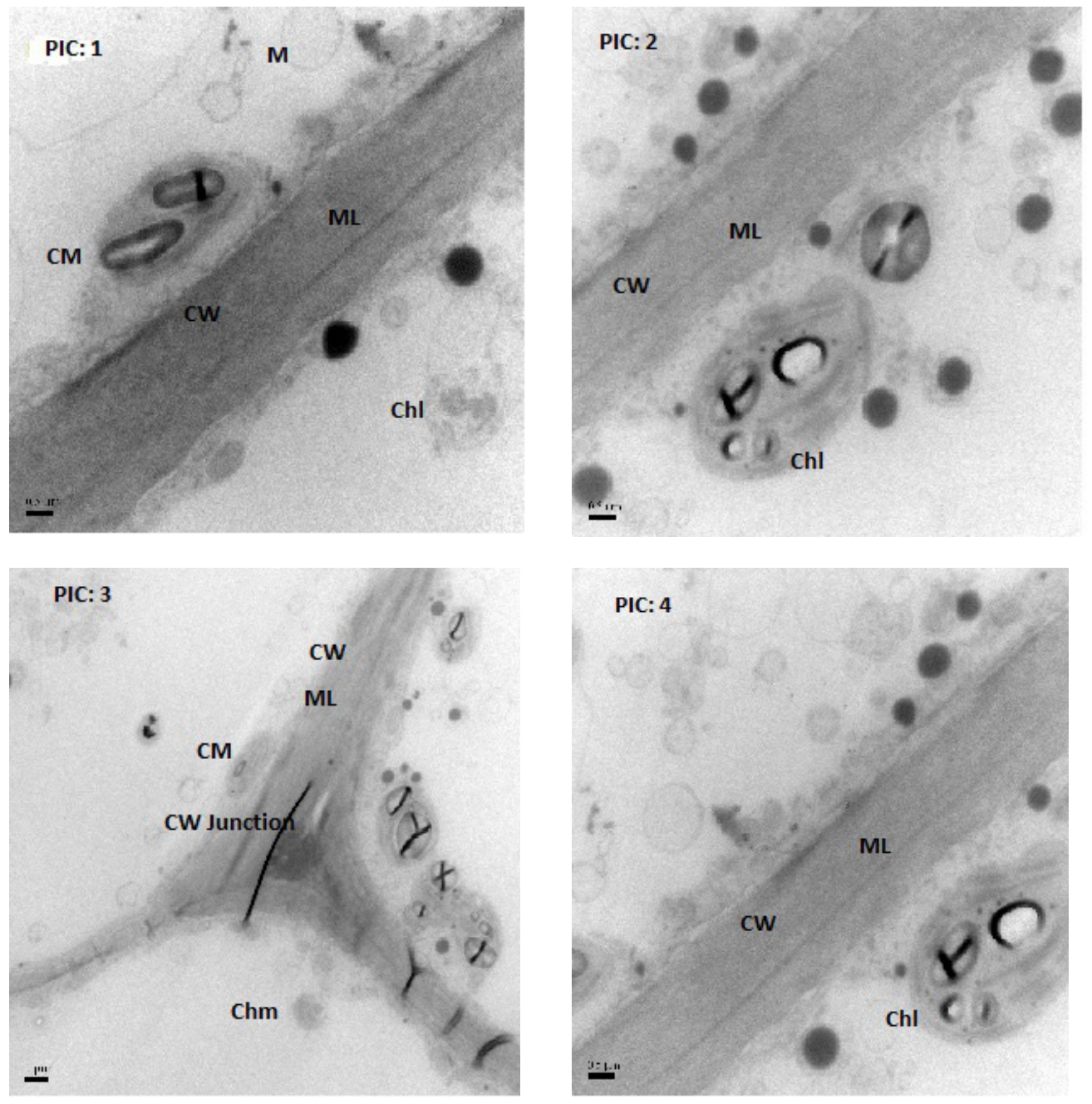

Figure 4. Compact and stout cell wall (CW) with integrated middle lamella (ML) was observed during green (PIC $=1)$ and breaker $(\mathrm{PIC}=2,3$ and 4$)$ stages of cultivar $\mathrm{MD}$ at normal ripening. Cytoplasm possessed many normal organelles including mitochondria (M), chloroplasts (Chl), and crystalloid microbodies (CM). The CW consists of fibrils in an electron-translucent matrix. ML is quite vivid as an electron dense region between walls of adjacent cells and cell wall structure is unchanged $(\mathrm{PIC}=1,2,3$, and 4$) . \mathrm{PIC}=1(0.5 \mu \mathrm{m}), \mathrm{PIC}=2(0.5 \mu \mathrm{m}), \mathrm{PIC}=3(1$ $\mu \mathrm{m})$, PIC $=4(0.5 \mu \mathrm{m})$. 

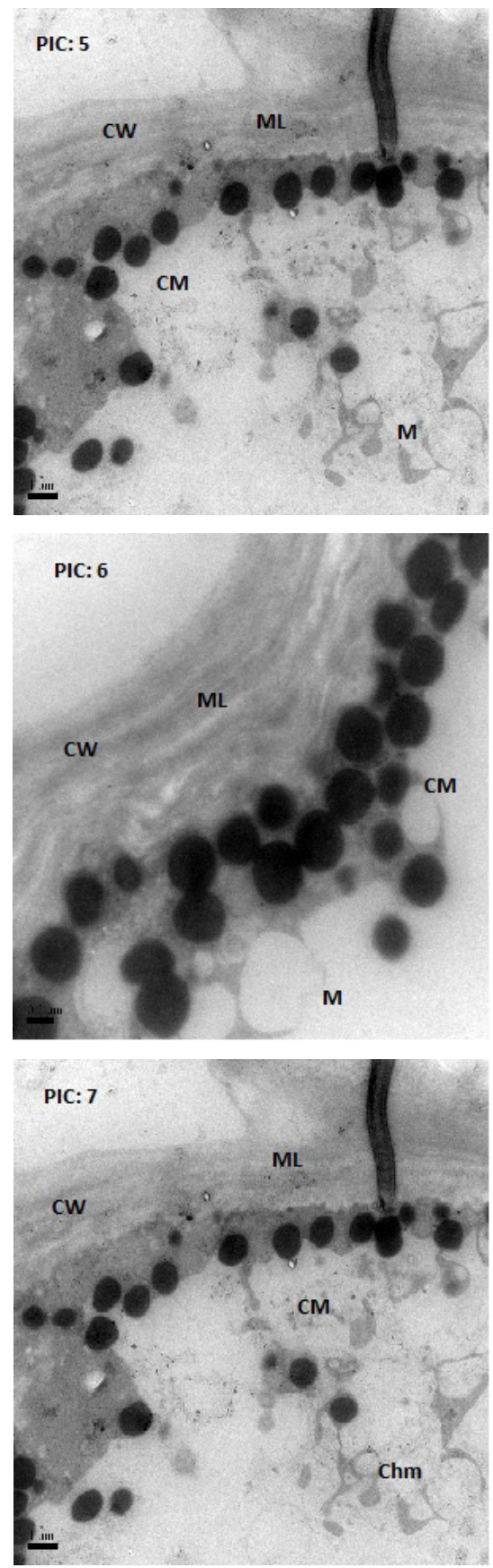

Figure 5. At the mature red stage, $P G$ activity was robust in cultivar $M D$ and there has been an increase in interfibrillar spaces of cell wall (CW), which clearly indicated that cell wall dissolution has been initiated along the middle lamella (ML). Cellular organelles like chromoplast $(\mathrm{Chm})$, crystalloid microbodies $(\mathrm{CM})$ and mitochondria (M) started crumbling $(\mathrm{PIC}=5,6$ and 7$) . \mathrm{PIC}=5(1 \mu \mathrm{m}), \mathrm{PIC}=6(0.5 \mu \mathrm{m})$ and $\mathrm{PIC}=7(1 \mu \mathrm{m})$. 

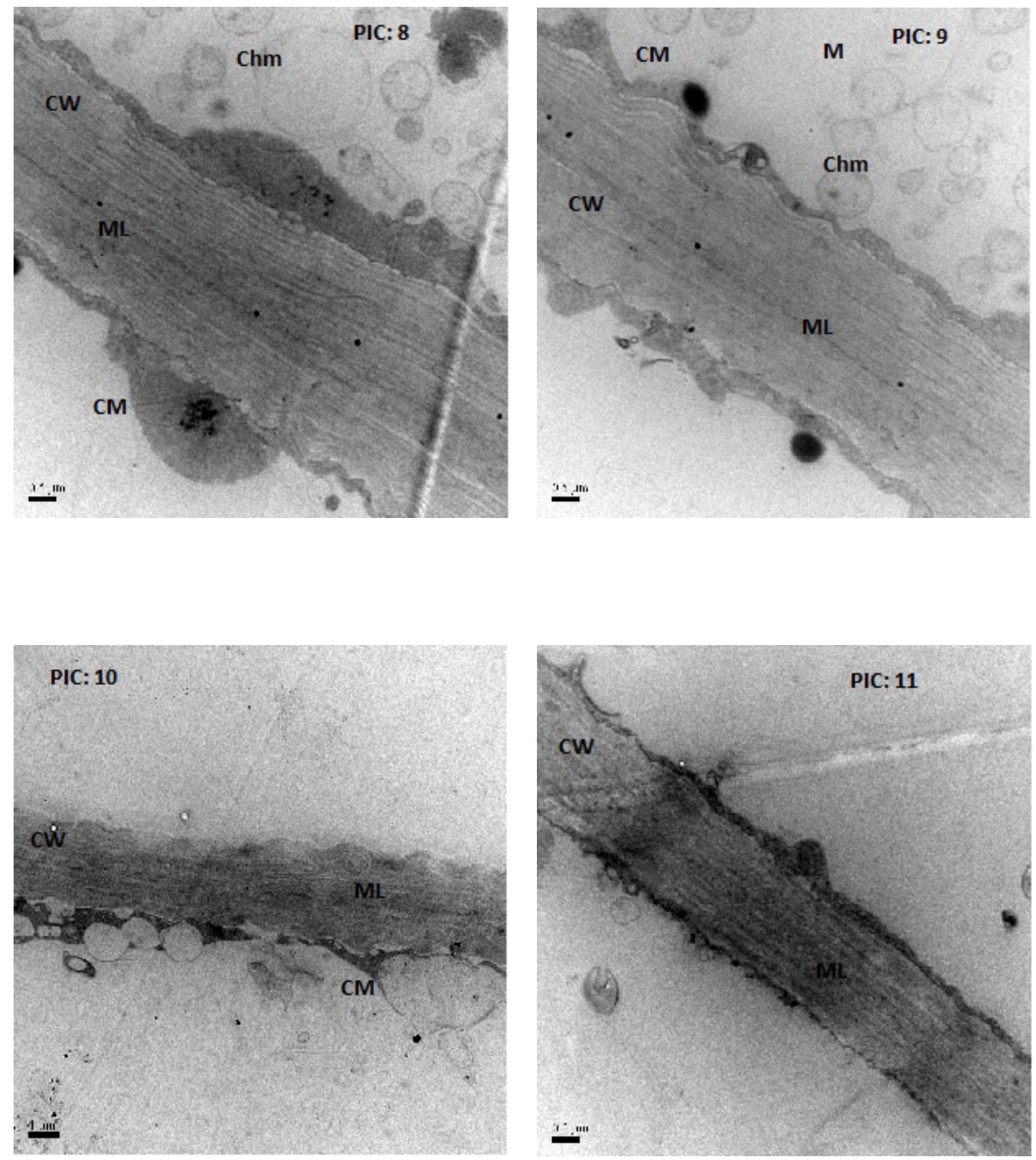

Figure 6. Changes in ultrastructure during normal ripening. $\mathrm{PIC}=8,9$ and 10 are at the green stage and PIC $=11$ is at the breaker stage of cultivar TLD, which showed compact and stout cell wall (CW) with integrated middle lamella (ML). Cytoplasm carried many normal cellular organelles including chloroplasts (Chl), chromoplasts $(\mathrm{Chm})$, crystalloid microbodies $(\mathrm{CM})$, and mitochondria $(\mathrm{M})$. The $\mathrm{CW}$ consists of fibrils in an electron-translucent matrix. The ML is quite firm as an electron dense region between walls of adjacent cells and cell wall structure remains unchanged. PIC $=8(0.5 \mu \mathrm{m}), \mathrm{PIC}=9(0.5 \mu \mathrm{m}), \mathrm{PIC}=10(1 \mu \mathrm{m}), \mathrm{PIC}=11(0.5 \mu \mathrm{m})$. 

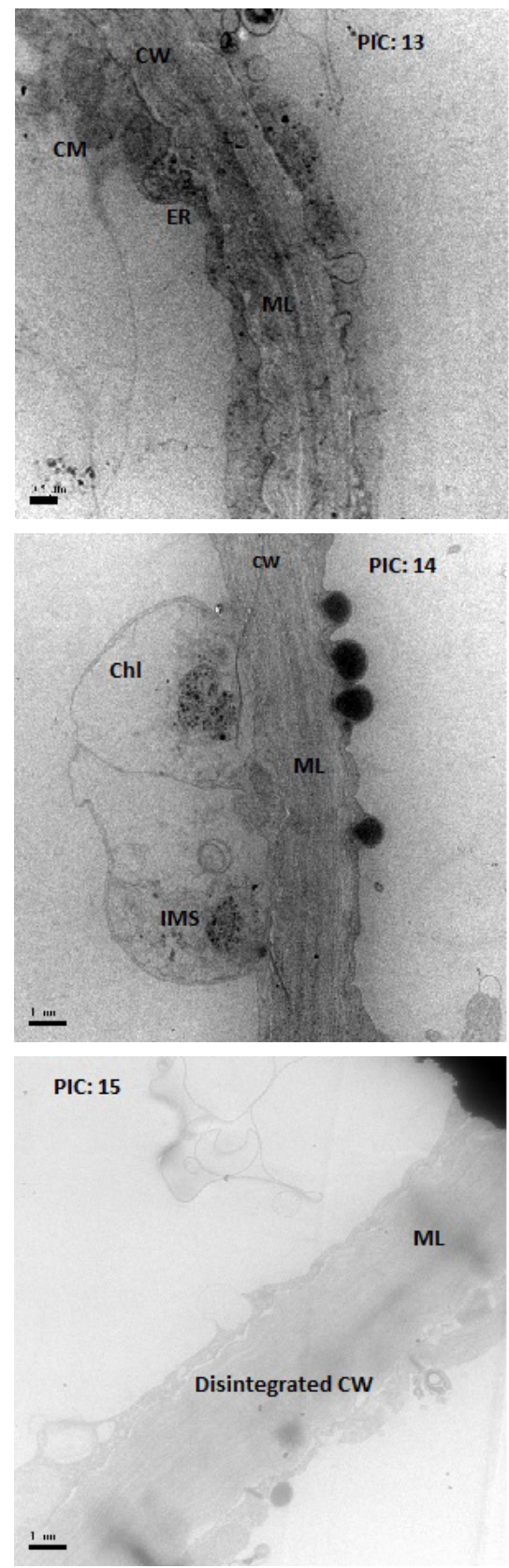

Figure 7. PG activity was in full swing in cultivar TLD during the mature yellow stage, and a distinguishable change was observed in interfibrillar spaces of cell wall $(\mathrm{CW})$, which clearly provided the evidence of cell wall dissolution along the middle lamella (ML). Cellular organelles like chromoplasts (Chm), crystalloid microbodies $(\mathrm{CM})$ and mitochondria $(\mathrm{M})$ had started to crumble. Plastid structure has been altered with angular lycopene crystalloid remnants being replaced by an intraplastid membrane system (IMS). PIC $=13(0.5 \mu \mathrm{m}), \mathrm{PIC}=14(1$ $\mu \mathrm{m})$ and $\mathrm{PIC}=15(1 \mu \mathrm{m})$. 


\section{DISCUSSION}

The mechanism of fruit ripening in various horticultural crops has been known for many years, and there is abundant evidence available to show that fruit ripening is a complex phenomenon. Our findings of PG activity, mainly responsible for fruit cell wall degradation and the transition of maturity stages, are in agreement with the findings of Arancibia and Motsenbocker (2006). Pectins are increasingly solubilized, and thus may contribute to their loss from the cell walls, resulting in softening during ripening (Huber, 1983; Ketsa and Daengkanit, 1999). This suggests that mature fruit may have greater activity of softening enzymes such as PG, contributing to the degradation of pectin cell walls (Hobson, 1965; Hasegawa et al., 1969; Zauberman and Schiffmann-Nadel, 1972; Nagy et al., 1985; Barrett and Gonzalez, 1994).

The highest PG activity occurred during the period when fruits gained the fully ripened stage between days 23 and 28 after harvest and coincided with the rapid loss of fruit firmness. The results are similar to the findings of scientists who worked on the role of PG during fruit development in various kinds of fruits and found a correlation, as PG activity and softening occurs simultaneously in cherry (Barrett and Gonzalez, 1994), date (Hasegawa et al., 1969), durian (Ketsa and Daengkanit, 1999), kiwifruit (Wang et al., 2000), mango (Ketsa et al., 1998), papaya (Paull and Chen, 1983), pear (Ahmed and Labavitch, 1980), pepper (Rao and Paran, 2003; Arancibia and Motsenbocker, 2006), tobacco (Osteryoung et al., 1990), and tomato (Hobson, 1965; Crookes and Grierson, 1983; Huber, 1983; DellaPenna et al., 1987; Bird et al., 1988; Biggs and Handa, 1989; Smith et al., 1990; Fenwick et al., 1996).

The cultivars MD and TLD softened continuously throughout the ripening stages, with the greatest change in softening occurring 20 to 23 days after picking. Also, there were significant differences in fruit weight and fruit length during the later stages of ripening. These results are similar to the findings of Arancibia and Motsenbocker (2006). Ketsa and Daengkani (1999) reported that PG influenced the mass deposition of fruit in durian during fruit developmental stages.

Cloning of molecular chaperones and performing RT-PCR is a very effective and useful tool to determine the strength and expression of a particular gene responsible for inducing fruit maturity (Wang et al., 2000; Li et al., 2010; Zhu et al., 2011).

We performed RT-PCR to quantify $C a P G$ gene expression during different ripening stages of the cultivars MD and TLD. The deduced amino acid sequence of $C a P G$ showed most similarity to active endo-PG enzyme isolated by Chen et al. (2010). There was little expression of $C a P G$ in the green stage of both cultivars, as also found by DellaPenna et al. (1987); Ketsa and Daengkanit, (1999), and Wang et al. (2000) reported that PG is not expressed at early stages of fruit maturity. $C a P G$ expression was quite weak during the breaker stage in $\mathrm{cv}$. MD and not seen in cv. TLD. However, strong bands of cloned molecular chaperones were obtained during the ripe stage of both cultivars MD and TLD. This suggests that PG enzyme reaches maximum activity and has robust expression at the ripe stage, as also found by DellaPenna et al. (1987), Osteryoung et al. (1990), Ketsa and Daengkanit (1999), and Wang et al. (2000).

Recently, electron microscopy has also provided insights into the biochemical and physiological changes that occur during fruit ripening (Khan et al., 2011). Until recently, it was widely held that the essential factor was the enzymatic depolymerization of pectin in some species (Brady, 1987; Jarvis, 1984). In addition, the softening of many ripening fruits is associated with alterations in cell wall and middle lamella structure (Seymour and Gross, 
1996). Therefore, to determine the potential role of PG enzyme in cell wall degradation, we conducted TEM to evaluate the potential role of PG enzyme in the degradation of the fruit cell wall.

The pattern of cell wall and middle lamella orientation at the green stage in both cultivars MD and TLD are shown in Figure 4; $\mathrm{PIC}=1$ and Figure 6; $\mathrm{PIC}=8,9,10$. At this stage, $\mathrm{PG}$ activity was approximately $0.55 \mu \mathrm{mol}$ galacturonic $\cdot \mathrm{g}$ fresh weight ${ }^{-1} \cdot \mathrm{h}^{-1}$ in $\mathrm{cv}$. MD, and $1.86 \mu \mathrm{mol}$ galacturonic acid.g fresh weight ${ }^{-1} \cdot \mathrm{h}^{-1}$ in $\mathrm{cv}$. TLD. However, PG did not influence the translucent matrix of the middle lamella and early damage to the cell wall. Similar results were observed by Crookes and Grierson (1983) in the tomato cell wall.

The pattern and orientation of the cell wall, middle lamella and other cellular organelles without distinguishable damage at the breaker stage in both cultivars MD and TLD are shown in Figure 4, PIC $=2,3,4$ and Figure 6, PIC $=11$. At this stage, PG activity was approximately $1.35 \mu \mathrm{mol}$ galacturonic acid.g fresh weight ${ }^{-1} \cdot \mathrm{h}^{-1}$ in $\mathrm{cv}$. MD and $2.43 \mu \mathrm{mol}$ galacturonic acid $\cdot g$ fresh weight ${ }^{-1} \cdot h^{-1}$ in cv. TLD. In contrast, PG did not influence the translucent matrix of the cell wall, middle lamella, or other cellular organelles. The results are contrary to the findings of Osteryoung et al. (1990); they observed greater changes in the cell wall of transgenic tobacco that occurred in PG activity of approximately 1.5 per $\mu \mathrm{mol}$ reducing groups $\cdot \mathrm{min}^{1} \cdot \mu \mathrm{g}^{-1}$. Interspecies differences might be one of the reasons for these observations.

The disruption of the cell wall, middle lamella and other cellular organelles with distinguishable damage at the fully matured stage in both cultivars MD and TLD are shown in Figure 5, PIC = 5, 6, 7 and Figure 7, PIC $=13,14,15$. At this stage, PG activity was approximately $5.48 \mu \mathrm{mol}$ galacturonic acid.g fresh weight ${ }^{-1} \cdot \mathrm{h}^{-1}$ in $\mathrm{cv}$. MD and $5.10 \mu \mathrm{mol}$ galacturonic acid.g fresh weight ${ }^{-1} \cdot h^{-1}$ in $\mathrm{cv}$. TLD. PG greatly influenced the translucent matrix of the cell wall, middle lamella, and other cellular organelles. At later stages, 25-30 days after the onset of polygalacturonase production, extensive wall disintegration was not observed in cultivars MD and TLD (Figures 5 and 7). The pattern of disruption was basically similar to that described earlier by Crookes and Grierson (1983) in the tomato cell wall, although much more dissolution of the primary cell wall was evident. Despite the difficulties of processing this type of delicate tissue for TEM, a large degree of cellular organization was retained in the cytoplasm of fully matured, soft fruit, chromoplasts, mitochondria, and endoplasmic reticulum, which are visible in Figure 7, PIC $=13$. PG caused dissolution of the middle lamella and the release of fibrous components of the primary cell wall into the resulting electron translucent region in cv. TLD (Figure 7, PIC = 15). The outer region of the wall was found to be composed of parallel arrays of fibers arranged in a pattern similar to the 'bow shapes' in cv. TLD shown by purified fungal PG (Roland and Vian, 1981; Crookes and Grierson, 1983).

\section{CONCLUSIONS}

The role of polygalacturonase during normal fruit ripening processes was demonstrated by RT-PCR and electron microscopy. In the near future, experiments will be aimed at developing transgenic plants of cultivars MD and TLD and evaluating the effect of the PG gene after being expressed under the control of promoters like CaMV35 and E8. A comparative study would be conducted between transgenic and nontransgenic peppers under the influence of PG to better understand of its role. 


\section{ACKNOWLEDGMENTS}

We are grateful to the National Natural Science Foundation of China (\#30571262 and \#1000906), the National High Technology Research and Development Program (\#2009AA10Z104-6) and Shaanxi Province Agriculture Science and Technology Projects (\#2010K01-25-1) for providing the funds.

\section{REFERENCES}

Ahmed AE and Labavitch JM (1980). Cell wall metabolism in ripening fruit II. Changes in carbohydrate-degrading enzymes in ripening 'Bartlett' pears. Plant Physiol. 65: 1014-1016.

Arancibia RA and Motsenbocker CE (2006). Pectin methylesterase activity in vivo differs from activity in vitro and enhances polygalacturonase-mediated pectin degradation in tabasco pepper. J. Plant Physiol. 163: 488-496.

Barrett DM and Gonzalez C (1994). Activity of softening enzymes during cherry maturation. Food Sci. 59: 574-577.

Biggs SM and Handa AK (1989). Temporal regulation of polygalacturonase gene expression in fruit of normal, mutant, and heterozygous tomato genotypes. Plant Physiol. 89: 117-125.

Bird CR, Smith CJS, Ray JA, Moureau P, et al. (1988). The tomato polygalacturonase gene and ripening-specific expression in transgenic plants. Plant Mol. Biol. 11: 651-662.

Brady CJ (1987). Annual review. Plant Physiol. 38: 155.

Brummell DA and Harpster MH (2001). Cell wall metabolism in fruit softening and quality and its manipulation in transgenic plants. Plant Mol. Biol. 47: 311-340.

Chen RG, Yang RP, Gong ZH, Li DW, et al. (2010). Cloning and sequence analysis of the polygalacturonase gene CaPG in pepper. Acta Bot. Boreal-Occidentalia Sin. 30: 1941-1945.

Crookes PR and Grierson D (1983). Ultrastructure of tomato fruit ripening and the role of polygalacturonase isoenzymes in cell wall degradation. Plant Physiol. 72: 1088-1093.

Del E, Perez MC, Álvarez CO, Arrazate ACH, et al. (2007). Morphological variation in Guajillo chilli pepper plant (Capsicum annum L.). Afr. Crop Sci. Conf. Proceed. 8: 327-332.

DellaPenna D, Kates DS and Bennett AB (1987). Polygalacturonase gene expression in rutgers, rin, nor and $\mathrm{Nr}$ tomato fruits. Plant Physiol. 85: 502-507.

Errington N, Mitchell JR and Tucker GA (1997). Changes in the force relaxation and compression responses of tomatoes during ripening: the effect of continual testing and polygalacturonase activity. Postharvest Biol. Tech. 11: 141-147.

Fenwick KM, Jarvis MC, Apperley DC, Seymour GB, et al. (1996). Polymer mobility in cell walls of transgenic tomatoes with reduced polygalacturonase activity. Phytochemistry 42: 301-307.

Geleta LF, Labuschagne MT and Viljoen CD (2005). Genetic variability in pepper (Capsicum annuum L.) estimated by morphological data and amplified fragment length polymorphism markers. Biodivers. Conserv. 14: 2361-2375.

Georgia O, Ilias I, Giannakoula A and Papadopoulou P (2010). Comparative study on the effects of various plant growth regulators on growth, quality and physiology of Capsicum annum L. Pak. J. Bot. 42: 805-814.

Giorno F, Wolters AM, Grillo S, Scharf KD, et al. (2010). Developmental and heat stress-regulated expression of HsfA2 and small heat shock proteins in tomato anthers. J. Exp. Bot. 61: 453-462.

Giovannoni JJ (2001). Molecular biology of fruit maturation and ripening. Annu. Rev. Plant Physiol. Plant Mol. Biol. 52: $725-749$.

Giovannoni JJ, DellaPenna D, Bennett AB and Fischer RL (1989). Expression of a chimeric polygalacturonase gene in transgenic rin (ripening inhibitor) tomato fruit results in polyuronide degradation but not fruit softening. Plant Cell 1: $53-63$.

Giovannoni JJ, DellaPenna D, Bennett A and Fischer R (1991). Polygalacturonase and tomato fruit ripening. Hort. Rev. 13: 67-103.

Hasegawa S, Maier VP, Kaszycki HP and Crawford JK (1969). Polygalacturonase content of dates and its relation to maturity and softness. J. Food Sci. 34: 527-529.

Hobson GE (1965). The firmness of tomato fruit in relation to polygalacturonase activity. J. Hort. Sci. 40: 66-72.

Huber DJ (1983). The role of cell wall hydrolases in fruit softening. Hort. Rev. 5: 169-219.

Jarvis MC (1984). Structure and properties of pectin gels in plant cell walls. Plant Cell Environ. 7: 153-164.

Ketsa S and Daengkanit T (1999). Firmness and activities of polygalacturonase, pectinesterase, $\beta$-galactosidase and cellulase in ripening durain harvested at different stages of maturity. Sci. Hort. 80: 181-188. 
Ketsa SS, Chidtragool S, Klein JD, Luire S, et al. (1998). Effect of heat treatment on changes in softening, pectic substances and activities of polygalacturonase, pectinesterase and $\beta$-galactosidase of ripening mango. J. Plant Physiol. 153: 457461.

Khan MA, Cheng ZH, Xiao XM, Khan AR, et al. (2011). Ultrastructural studies of the inhibition effect against Phytophthora capsici of root exudates collected from two garlic cultivars along with their qualitative analysis. Crop Prot. 30: 1149-1155.

Li YG, Zheng YZ, Feng FZ, Liang D, et al. (2010). Overexpression of a Malus vacuolar $\mathrm{Na}^{+} / \mathrm{H}^{+}$antiporter gene $(M d N H X 1)$ in apple rootstock M.26 and its influence on salt tolerance. Plant Cell Tiss. Org. Cult. 102: 337-345.

Nagy S, Marshall W, Wardowski WF and Rouseff RL (1985). Postharvest creasing of Robinson tangerines as affected by harvest date, pectinesterase activity and calcium content. J. Hort. Sci. 60: 137-140.

Osteryoung KW, Toenjes K, Hall B, Winkler V, et al. (1990). Analysis of tomato polygalacturonase expression in transgenic tobacco. Plant Cell 2: 1239-1248.

Paull RE and Chen NJ (1983). Postharvest variation in cell wall-degrading enzymes of papaya (Carica papaya L.) during fruit ripening. Plant Physiol. 72: 382-385.

Peigen ZL, Zhouyou Q, Xiaoyu and Bangliang W (1991). The relationship between fruit softening and changes in pectin and relative enzymes during ripening of peaches. J. Nanjing Agric. Univ. China 14: 33-37.

Rao GU and Paran I (2003). Polygalacturonase: a candidate gene for the soft flesh and deciduous fruit mutation in Capsicum. Plant Mol. Biol. 51: 135-141.

Roland JC and Vian B (1981). Use of purified endopolygalacturonase for a topochemical study of elongating cell walls at the ultrastructural level. J. Cell Sci. 48: 333-343.

Seymour GB and Gross KC (1996). Cell wall disassembly and fruit softening. Postharvest News Inform. 7: 45-52.

Smith CJ, Watson CF, Bird CR, Ray J, et al. (1990). Expression of a truncated tomato polygalacturonase gene inhibits expression of the endogenous gene in transgenic plants. Mol. Gen. Genet. 224: 477-481.

Themmen AP, Tucker GA and Grierson D (1982). Degradation of isolated tomato cell walls by purified polygalacturonase in vitro. Plant Physiol. 69: 122-124.

Wang ZY, MacRae EA, Wright MA, Bolitho KM, et al. (2000). Polygalacturonase gene expression in kiwifruit: relationship to fruit softening and ethylene production. Plant Mol. Biol. 42: 317-328.

Xue GP and Loveridge CW (2004). HvDRF1 is involved in abscisic acid-mediated gene regulation in barley and produces two forms of AP2 transcriptional activators, interacting preferably with a CT-rich element. Plant J. 37: 326-339.

Yoshida K and Komae K (2006). A rice family 9 glycoside hydrolase isozyme with broad substrate specificity for hemicelluloses type II cell wall. Plant Cell Physiol. 47: 1541-1554.

Zauberman GM and Schiffmann-Nadel M (1972). Pectinmethylesterase and polygalacturonase in avocado fruit at various stages of development. Plant Physiol. 49: 864-865.

Zhu W, Lu MH, Gong ZH and Cheng RG (2011). Cloning and expression of a small heat shock protein gene CaHSP24 from pepper under abiotic stress. Afri. J. Biotechnol. 10: 4968-4976. 